\title{
Crop Response Based Assessment of Soil Fertility through Nutrient Omission Technique in Alfisol of Bastar District of Chhattisgarh State in India
}

\author{
Bhupendra Kumar ${ }^{1}$, G.K. Sharma ${ }^{1}$, V.N. Mishra ${ }^{2}$, \\ T. Chandrakar ${ }^{1}$ and Thalesh Kumar ${ }^{1}$
}

${ }^{1}$ Indira Gandhi Krishi Vishwavidyalaya, Shaheed Gundadhur College of Agriculture and Research Station, Jagdalpur - 494005 (Bastar), Chhattisgarh, India

${ }^{2}$ Indira Gandhi Krishi Vishwavidyalaya, Department of Soil Science \& Agricultural Chemistry, College of Agriculture, Raipur-492006, Chhattisgarh, India

*Corresponding author

\section{Ke y w o r ds \\ Nutrient omission pot technique, Site specific nutrient management, Yield limiting nutrients, Crop response, Soil fertility}

\section{Article Info}

Accepted:

10 July 2020 Available Online: 10 August 2020

\section{A B S T R A C T}

A missing nutrient pot experiment for assessment of yield limiting nutrients in soil was under taken during kharif and rabi season 2017-18 at Shaheed Gundadhur College of Agriculture and Research Station, Jagdalpur (Chhattisgarh). The pot experiment, during kharif season with transplanted rice, was laid out under completely randomized design with three replications and 11 treatments comprised with keeping one treatment of all nutrients $(\mathrm{N}, \mathrm{P}, \mathrm{K}, \mathrm{S}, \mathrm{Fe}, \mathrm{Mn}, \mathrm{Cu}, \mathrm{Zn}, \mathrm{B}$, and $\mathrm{Mo}$ ) applied in optimum level and other treatments were formulated by sequentially omitting each nutrient from all nutrients treatment. The result revealed that the omission of nutrients $\mathrm{N}, \mathrm{P}, \mathrm{Zn}$ and B significantly reduced the plant height, tillers pot ${ }^{-1}$, effective tillers pot ${ }^{-}$ ${ }^{1}$, filled grains panicle ${ }^{-1}$, grain and straw yield of rice and uptake of $\mathrm{N}, \mathrm{P}, \mathrm{K}, \mathrm{S}, \mathrm{Ca}$, $\mathrm{Mg}, \mathrm{Cu}, \mathrm{Zn}, \mathrm{Mn}, \mathrm{Fe}$ and $\mathrm{B}$ by rice in comparison to treatment that received all nutrients. The highest grain yield $90.6 \mathrm{~g} \mathrm{pot}^{-1}$ were recorded under the treatment receiving all the nutrients and that of lowest grain yields $40.8 \mathrm{~g} \mathrm{pot}^{-1}$ were recorded under omission of $\mathrm{N}$, followed by omission of $\mathrm{P}\left(60.2 \mathrm{~g} \mathrm{pot}^{-1}\right) \mathrm{Zn}\left(72.9 \mathrm{~g} \mathrm{pot}^{-1}\right)$ and $\mathrm{B}$ (78.4 $\left.\mathrm{g} \mathrm{pot}^{-1}\right)$ nutrients. Based on these results of kharif season, the limiting nutrients were identified as $\mathrm{N}, \mathrm{P}, \mathrm{Zn}$ and $\mathrm{B}$. These nutrients were applied at the rate of $150 \mathrm{~kg}$ $\mathrm{N}, 100 \mathrm{~kg} \mathrm{P}_{2} \mathrm{O}_{5}, 100 \mathrm{~kg} \mathrm{~K}_{2} \mathrm{O}, 7.5 \mathrm{~kg} \mathrm{Zn} \mathrm{ha}^{-1}$, and $3 \mathrm{~kg} \mathrm{~B} \mathrm{ha}^{-1}$. This site specific nutrient dose was tested with wheat crop during rabi season 2017-18 at same farmers field, from where the bulk soils were collected for kharif pot experiment. Site specific nutrient dose based on identified yield limiting nutrients resulted about 14-17 percent increase in grain yield of wheat over farmer's fertilizer dose at the rate of $80 \mathrm{~kg} \mathrm{~N}: 50$ $\mathrm{kg} \mathrm{P}_{2} \mathrm{O}_{5}: 0 \mathrm{~kg} \mathrm{~K}_{2} \mathrm{O} \mathrm{ha}{ }^{-1}$. 


\section{Introduction}

Among the various cropping systems, ricebased cropping systems are the predominant systems in India. Managing the variability in soil nutrient supply that has resulted from intensive rice cropping is one of the challenges for sustaining and increasing rice yield in India. The use of plant nutrients in a balanced manner is the prime factor for efficient fertilizer program. Balanced nutrient use ensures high production level and helps to maintain the soil health and ensures sustainable agriculture (Sahu et al., 2017).

For adequate and balanced fertilization of crops in high crop production systems, soil fertility evaluation considered as the key factor. To assess the fertility status of a soil, plant and soil analyses are commonly performed with other diagnostic techniques including identification of deficiency symptoms and biological tests which are helpful in determining specific nutrient stresses and quantity of nutrients needed to optimize the yield (Havlin et al., 2007), however, the analytical results do not indicate the most limiting nutrient according to Liebig's law of the minimum "the minimum nutrient is the factor that governs and controls growth and potential yield of crop".

Chhattisgarh state has four major soils types i.e. Entisols, Inceptisols, Alfisols, and Vertisols. Almost all soils are deficient in nitrogen and phosphorus and medium to high in potassium. Zinc deficiency is commonly observed in Alfisols and Vertisols. In view of intensive cropping with continuous use of $\mathrm{S}$ free complex fertilizers, chances of $S$ deficiency may also occur.

Other micronutrients like $\mathrm{Fe}, \mathrm{Mn}, \mathrm{Cu}, \mathrm{B}$ and Mo may be sufficient for low to medium level of crop production but may not be sufficient for high level of crop production. High crop yields can only be achieved when high yielding crop varieties are properly nourished in a correct amount and proper ratios. In addition to this limitation, low fertilizer efficiency, inadequacy of current fertilizer recommendations and the ignorance of nutrients other than $\mathrm{N}, \mathrm{P}$, and $\mathrm{K}$ may limit crop production.

A nutrient omission pot trial provides a visible order of crop response to nutrient application. It aims to find out the most limiting nutrients to the growth of a crop plant. If any element is omitted while other elements are applied at suitable rates and plants grow weakly, then the tested element is a limiting factor for crop growth. Conversely, if any element is omitted but plants are healthy, then that element is not a limiting factor for crop production.

The site-specific nutrient management strives to enable farmers to dynamically adjust fertilizer use to optimally fill the deficit between the nutrient needs of a high-yielding crop and the nutrient supply from naturally occurring indigenous sources such as soil, organic amendments, crop residues, manures, and irrigation water. This approach does not specifically aim to either reduce or increase fertilizer use; instead, it aims to apply nutrients at optimal rates and times to achieve high yield and high efficiency of nutrient use by the rice crop, leading to high cash value of the harvest per unit of fertilizer invested.

Looking to very limited information on the proper and site specific nutrient doses to maximize yield of rice, present investigation was undertaken with the objective to assess the yield limiting nutrients based on rice response using nutrient omission technique and to demonstrate the optimum use of identified limiting nutrients and its comparison with farmer's fertilizer practice. 


\section{Materials and Methods}

The investigation for assessment of yield limiting nutrients in soil was undertaken during the year 2017-18 at the green house of Section of Soil Science and Agricultural Chemistry, Shaheed Gundadhur College of Agriculture and Research Station, Jagdalpur, Bastar (Chhattisgarh) and subsequently at farmers field of village - Dharmaur, block Tokapal, District -Bastar for velidation of the results of pot experiment. The study site lies at $19^{0} 10^{\prime} \mathrm{N}$ latitude and $81^{\circ} 95 \mathrm{E}$ longitude with an altitude of 550-760 meter above the mean sea level. The pot experiment, during kharif season with transplanted rice, was laid out under Completely Randomized Design (CRD) with three replications and 11 treatments comprised by keeping one treatment with application of all nutrients $(\mathrm{N}$, $\mathrm{P}, \mathrm{K}, \mathrm{S}, \mathrm{Fe}, \mathrm{Mn}, \mathrm{Cu}, \mathrm{Zn}, \mathrm{B}$, and $\mathrm{Mo}$ ) in optimum level and other treatments were formulated by sequentially omitting each nutrient from all nutrients treatment.

The bulk soil samples representative of Alfisol of the district was collected from the farmer's fields before conducting the pot culture experiment to identify the yield limiting nutrients. The initial physicochemical characteristics of the experimental soil (Alfisol) were determined (Table1) using common field and laboratory procedures. The initial status of soil $\mathrm{pH}$ was, recorded as neutral (6.6). Electrical Conductivity (EC) were estimated as $\left(0.18 \mathrm{dsm}^{-1}\right)$ and rated as normal. The organic Carbon was estimated as $(0.57 \%)$ in the soils where it was rated as medium. Available $\mathrm{N}$ and $\mathrm{S}$ were estimated as low. Status in available $\mathrm{P}$ and $\mathrm{K}$ was rated as medium and that of available $\mathrm{Ca}$ and $\mathrm{Mg}$ was high. The available $\mathrm{Zn}$ and $\mathrm{B}$ were rated as marginal; however, the availability of $\mathrm{Cu}, \mathrm{Mn}$ and $\mathrm{Fe}$ was rated as high.

The processed and uniformed soil samples were filled in plastic pots @ $20 \mathrm{~kg}$ and nutrients as specified above were applied through different sources taking care to avoid any precipitation during solution mixing and application. The optimum doses of nutrients were fixed in $\mathrm{kgha}^{-1}$ as $\mathrm{N}-150, \mathrm{P}_{2} \mathrm{O}_{5^{-}} 100$, $\mathrm{K}_{2} \mathrm{O}-100, \mathrm{~S}-45, \mathrm{Fe}-20, \mathrm{Mn}-7.5, \mathrm{Cu}-7.5$, $\mathrm{Zn}-7.5$, B - 3 and Mo - 0.75 for SSNM dose. Rice (MTU-1001) was taken as test crop. The pots were maintained saturation with standing water and twenty-five days old seedlings of rice (MTU-1001) were transplanted on $22^{\text {th }}$ July 2017. Three seedlings of MTU-1001 variety of rice were planted in three hills in each pot and water level was maintained at 3 $\mathrm{cm}$ throughout the crop season. Thereafter, full dose of all the nutrients except nitrogen was added to the soil in solution form. Nitrogen as urea was applied in three splits at transplanting, tillering and panicle initiation stage. The effects of treatments were recorded in terms of yield, different yield attributing parameters and nutrient uptake by rice crop. Based on these results, N, P, Zn and B were identified as yield limiting nutrients. The optimum use of identified limiting nutrients was verified at farmer's field, from where the bulk soil was collected, with wheat variety GW-273 as a test crop during rabi season 2017-18 and the effects of optimum/SSNM dose was compared with farmer's fertilizer practice

\section{Results and Discussion}

\section{Growth and yield parameters}

\section{Plant height}

The data presented in table 2 showed that the plant height of rice at maturity was affected significantly with various nutrient omission treatments imposed. The highest plant height of rice was recorded under treatment $T_{1}$ where all the nutrients were supplied in soil types at the locations, whereas significantly lower plant height were recorded under the treatments missing $\mathrm{N}, \mathrm{P}, \mathrm{Zn}$ and $\mathrm{B}$ nutrients in 
Alfisol at the locations of Bastar district, as compared to $\mathrm{T}_{1}$ indicating the need of application of these nutrients in different soil types of the region. Since $\mathrm{N}$ is an important constituent of amino acids, proteins and protoplast, its application had a more pronounced effect on plant growth and development through better utilization of photo-synthates and more vegetative growth.

These results are in conformity of the findings of Singh, (2008) and Sharma et al., (2000). P omission had also exhibited a significant effect on plant height. Optimum $P$ availability is essential for normal growth and development and the utilization of other nutrients, particularly N. The significant crop response to $\mathrm{P}$ application was also reported by many workers (Ahmed et al., 2010, Mc Beath et al., 2007, Kumar Balwant et al., 2018 and Kumar Bhupendra et al., 2018).

\section{Tillers per pot}

The data revealed that the number of tillers per pot of rice was significantly influenced by different missing nutrient treatments imposed (table 2). Significantly higher number of tillers was observed at treatment that received all the nutrients. However, treatment missing $\mathrm{N}, \mathrm{P}, \mathrm{Zn}$ and $\mathrm{B}$ were observed significantly lower numbers of tillers of rice as compared to treatment with all nutrients. $\mathrm{N}$ plays a key role in tillers bearing of rice followed by $\mathrm{P}$.

On an average, 25 tillers were observed at 60 DAT with $\mathrm{T}_{1}$ treatment in all soil types which received all nutrients and various nutrients omission treatments had reduced number of tillers.

Omission of $\mathrm{N}$ and $\mathrm{P}$ reduced the number of tillers as these two nutrients have major role in tillers bearing of the crop. Many researchers have also concluded the importance of $\mathrm{N}$ and $\mathrm{P}$ in tillering of the crops.

\section{Effective tillers pot $^{-1}$}

The data, pertaining to number of effective tillers per pot, presented in Table 2 was ranged from 13.3 to 21.7. Grain yield of cereals is highly dependent upon the number of effective tillers. Omission of different nutrients significantly reduced the number of effective tillers of rice. The highest numbers of effective tillers were observed in treatment $\mathrm{T}_{1}$ that received all nutrients. Omission of $\mathrm{N}$, $\mathrm{P}, \mathrm{Zn}$ and $\mathrm{B}$ nutrients significantly reduced the effective tillers of rice, as compared to treatment that received all nutrients.

\section{Filled grains panicle ${ }^{-1}$}

The number of filled grains panicle ${ }^{-1}$ as affected by various treatments varied from 121.3to 168.7 (table 2). Treatment which received all nutrients recorded significantly highest number of filled grains per panicle. Omission of $\mathrm{N}, \mathrm{P}, \mathrm{Zn}$ and $\mathrm{B}$ significantly reduced the filled grains per panicle, as compared to treatment receiving all nutrients.

\section{Test weight}

In this study, test weight (weight of 1000 rice seed) of rice did not differ significantly with respect to the application of different treatments (table 2). However, omission of $\mathrm{N}$ and $\mathrm{P}$ pots had reduced the test weight as compared to those of all other treatments. It is universally truth that $\mathrm{N}$ and $\mathrm{P}$ are the most important major nutrients require for tillering, root growth and general plant vigour that affect ultimately filled grains and test weight. The reduced effective tillers, number of filled grains per panicle and test weight were recorded in present study caused due to omission of $\mathrm{N}$ and $\mathrm{P}$ treatments.

\section{Grain yield}

The rice grain yields were influenced significantly with the imposition of different 
nutrient omission treatments (table 2). The highest grain yield (90.6 $\left.\mathrm{g} \mathrm{pot}^{-1}\right)$ were recorded under the treatment receiving all the nutrients $\left(\mathrm{T}_{1}\right)$ and that of significantly lower grain yields (40.8 $\mathrm{g} \mathrm{pot}^{-1}$ ) in comparison to $\mathrm{T}_{1}$, were recorded under omission of $\mathrm{N}$ followed by omission of $\mathrm{P}\left(60.2 \mathrm{~g} \mathrm{pot}^{-1}\right) \mathrm{Zn}$ (72.9 $\left.\mathrm{g} \mathrm{pot}^{-1}\right)$ and B (78.4 $\left.\mathrm{g} \mathrm{pot}^{-1}\right)$ nutrients. In other treatments, grain yields were observed statistically at par in comparison to treatment where all the nutrients were supplied to rice crop.

\section{Grain yield reduction}

The reduction in rice grain yield because of omission of different plant nutrients, from treatment where all the nutrients applied, were also worked out (table 2). The yield limiting nutrients which reduced the yield by about $10 \%$ from the maximum yield obtained by treatment with all nutrients are critically observed. It was noticed that omission of $\mathrm{N}$ from SSNM dose reduced the grain yield by $55.0 \%$ and that of $\mathrm{P}$ omission caused a yield reduction of $33.6 \%$. Apart from the omission of $\mathrm{N}$ and $\mathrm{P}$, yield reductions due to $\mathrm{Zn}$ and $\mathrm{B}$ omission were also noticed.

It was observed that $\mathrm{Zn}$ omission reduced rice yield by $19.6 \%$ and B omission $13.4 \%$. Percent reduction in rice grain yields under different nutrient omitted pots as presented in (Table 2) may be put in the order of $\mathrm{N}>\mathrm{P}$ $>\mathrm{Zn}>\mathrm{B}$. Large reductions in the grain yield of rice were observed with the omission of $\mathrm{N}$ and $\mathrm{P}$ as compared to the other nutrient omission treatments. The yield reductions were more pronounced with $\mathrm{N}$ omission. Result clearly indicates that $\mathrm{N}$ is the most critical nutrients that affect the grain yield considerably in all the soils followed by $\mathrm{P}$. Omission of all other nutrients did not indicate yield reduction, statistically significantly except, omission of $\mathrm{Zn}$ and B.

\section{Straw yield}

The mean straw yields of rice were significantly affected with imposition of different nutrient omission treatments (table 2). Omission of $N, P, Z n$ and $B$ significantly reduced the straw yield as compared to treatment where all the nutrients were supplied. The highest straw yield (111.5 g pot $^{-1}$ ) of rice was observed in treatment where all the nutrients were applied and lowest (55.5 $\mathrm{g} \mathrm{pot}^{-1}$ ) in treatment where $\mathrm{N}$ was omitted.

\section{Primary nutrients uptake}

\section{Nitrogen}

The nitrogen uptake by rice was significantly affected with application of different missing nutrient treatments (table 3). Omission of $\mathrm{N}$, $\mathrm{P}, \mathrm{Zn}$ and $\mathrm{B}$ in Alfisol of Bastar district significantly reduced the $\mathrm{N}$ uptake by rice as compared to treatment where all the nutrients were supplied. The highest $\mathrm{N}$ uptake of $1.58 \mathrm{~g}$ pot $^{-1}$ was recorded in the treatment that received all the nutrients and that of the lowest $\mathrm{N}$ uptake of $0.70 \mathrm{~g} \mathrm{pot}^{-1}$ was recorded in the pots where $\mathrm{N}$ was omitted. Supply of all the nutrients including nitrogen in "All" treatment increased the grain and straw yields as well as the nitrogen concentrations causing more uptake of $\mathrm{N}$ (Syed et al., 2006). Minimum nitrogen uptake was observed with nitrogen omission because nitrogen was the most yield limiting nutrient which resulted in lower yields and lower nitrogen uptake. The similar findings were also reported by Mishra et al., (2007), Kumar Balwant et al., (2018) and Kumar Bhupendra et al., (2018).

\section{Phosphorus}

Significant reduction in the total $\mathrm{P}$ uptake by rice was observed upon omission of $\mathrm{N}, \mathrm{P}, \mathrm{Zn}$ and $\mathrm{B}$ as compared to treatment where all the nutrients were supplied (table 3). All the other 
nutrient omission treatments were found statistically at par with the treatment receiving all nutrients. The highest total uptake of $\mathrm{P}$ by rice was recorded to the tune of $0.30 \mathrm{~g} \mathrm{pot}^{-1}$ under the treatment where all the nutrients were applied. The lowest total P uptake $(0.13$ $\mathrm{g} \mathrm{pot}^{-1}$ ) by rice was observed in the $\mathrm{N}$ missing treatment followed by $\mathrm{P}, \mathrm{Zn}$ and $\mathrm{B}$ omission treatments. Reductions in $\mathrm{P}$ concentration with omission of $\mathrm{P}$ have been reported by Din et al., (2001) for chickpea. Supply of $\mathrm{P}$ in "All" treatment increased the soil solution $\mathrm{P}$ causing higher absorption of $\mathrm{P}$ resulting in higher grain and straw yields as well more uptake of $\mathrm{P}$ because $\mathrm{P}$ was the next most yield limiting nutrient after $\mathrm{N}$, which resulted in lower yields and lower $\mathrm{P}$ concentrations.

\section{Potassium}

Omission of $\mathrm{N}, \mathrm{P}, \mathrm{Zn}$ and $\mathrm{B}$ significantly reduced the total $\mathrm{K}$ uptake by rice as compared to treatment where all the nutrients were supplied (Table 3). All the other nutrient omission treatments were found statistically at par with the treatment receiving all nutrients. The highest $\mathrm{K}$ uptake $\left(1.94 \mathrm{~g} \mathrm{pot}^{-1}\right)$ was registered in the treatment that received all the nutrients and the lowest $\mathrm{K}$ uptake (0.94 $\mathrm{g} \mathrm{pot}^{-1}$ ) in the $\mathrm{N}$ omission treatment.

\section{Secondary nutrients uptake}

\section{Calcium uptake}

The treatment that received all the nutrients was observed with the highest $\mathrm{Ca}$ uptake $\left(0.99 \mathrm{~g} \mathrm{pot}^{-1}\right)$ by rice crop (table 3$)$. Omission of $\mathrm{N}, \mathrm{P}, \mathrm{Zn}$ and $\mathrm{B}$ nutrients significantly reduced the $\mathrm{Ca}$ uptake in comparison to treatment receiving all nutrients, and the least uptake (0.48 and $\left.\mathrm{g} \mathrm{pot}^{-1}\right)$ was observed in $\mathrm{N}$ omission followed by $\mathrm{P}\left(0.66 \mathrm{~g} \mathrm{pot}^{-1}\right) \mathrm{Zn}(0.81$ $\left.\mathrm{g} \operatorname{pot}^{-1}\right)$ and $\mathrm{B}\left(0.82 \mathrm{~g} \mathrm{pot}^{-1}\right)$ omission pots. Omission of N, P, Zn and B reduced the total $\mathrm{Ca}$ uptakes by rice in comparison to the treatments receiving all the nutrients. Omission of $\mathrm{N}, \mathrm{P}, \mathrm{Zn}$ and $\mathrm{B}$ reduced the uptakes more than that of omission of other nutrients indicating that these nutrients were the most limiting nutrients. Lower $\mathrm{Ca}$ uptakes were observed with $\mathrm{N}, \mathrm{P}, \mathrm{Zn}$ and $\mathrm{B}$ omission obviously due to lower grain and straw yields and lower $\mathrm{Ca}$ concentrations. Uptakes of $\mathrm{Ca}$ in $\mathrm{N}, \mathrm{P}, \mathrm{Zn}$ and $\mathrm{B}$ omitted pots were in the order of $\mathrm{N}<\mathrm{P}<\mathrm{Zn}<\mathrm{B}$ in accordance with the grain and straw yields and $\mathrm{Ca}$ concentrations in the respective pots. Least reductions in $\mathrm{Ca}$ uptakes were observed with omission of $\mathrm{K}, \mathrm{S}, \mathrm{Cu}$, and Mo suggesting their sufficient level in the experimental soil.

\section{Magnesium uptake}

The highest total uptake of $\mathrm{Mg}\left(0.59 \mathrm{~g} \mathrm{pot}^{-1}\right)$, was observed with the treatment receiving all the nutrients, because supply of all the nutrients including $\mathrm{Mg}$ in all nutrients treatment increased the grain and straw yields as well as the $\mathrm{Mg}$ concentrations causing more uptake of $\mathrm{Mg}$, whereas, the least $\mathrm{Mg}$ uptake $\left(0.27 \mathrm{~g} \mathrm{pot}^{-1}\right)$ were observed with $\mathrm{N}$ omission treatment. Reduced Mg uptake was observed with $\mathrm{N}, \mathrm{P}, \mathrm{Zn}$ and $\mathrm{B}$ omission treatments, since these were the most yield limiting elements. Mg uptakes were found almost similar in all the other treatments in comparison to treatment receiving all nutrients which might be due to higher initial $\mathrm{Mg}$ content in the soil under study. Uptakes of $\mathrm{Mg}$ in N, P, Zn and B omitted pots were in the order of $\mathrm{N}<\mathrm{P}<\mathrm{Zn}<\mathrm{B}$ in accordance with the grain and straw yields and $\mathrm{Mg}$ concentrations in the respective pots (Table 3 ).

\section{Sulphur uptake}

The highest $\mathrm{S}$ uptake $\left(0.24 \mathrm{~g} \mathrm{pot}^{-1}\right)$ was recorded in treatment which received all nutrients and the least total uptake of $S(0.12$ $\mathrm{g}$ pot $^{-1}$ ) was observed in the treatment that omit $\mathrm{N}$ nutrient. Omission of $\mathrm{N}, \mathrm{P}, \mathrm{Zn}$ and $\mathrm{B}$ 
caused significantly lower uptake of $S$, in comparison to treatment that received all the nutrients (table 3 ).

\section{Micronutrients uptake}

\section{Boron uptake}

The data presented in table 3 clearly indicated that the mean total $\mathrm{B}$ uptake by rice in the soils was significantly affected with application of different missing nutrient treatments. N, P, Zn, and B significantly reduced the uptake of $B$ as compared to treatment receiving all nutrients. Omission of $\mathrm{N}$ caused more reduction in uptake of $\mathrm{B}$ than that of $\mathrm{P}$ omission. The highest $\mathrm{B}$ uptake (1.59 mg pot ${ }^{-1}$ ) was recorded in treatment receiving all nutrients. The lowest uptake of $\mathrm{B}$ $\left(0.71 \mathrm{mg} \mathrm{pot}^{-1}\right)$ was recorded in the treatment of $\mathrm{N}$ omission. B uptake in $\mathrm{K}, \mathrm{S}, \mathrm{Fe}, \mathrm{Mn}, \mathrm{Cu}$ and Mo omission pots were at par with each other and with the treatment receiving all the nutrients. Reductions in concentration of $\mathrm{B}$ with omission of B have been reported by Din et al., (2001) in chickpea. An increase in B removal in plant tissues is obvious as B application along with other nutrients had increased available boron in soils resulting in higher absorption (Chander et al., 2007). Lower B uptake was observed with $\mathrm{N}$ and $\mathrm{P}$ omission because of lower grain and straw yields and lower B concentrations associated with these treatments.

\section{Iron uptake}

The uptake of iron by rice was significantly affected by omission of different nutrients (table 3). Omission of N, P, Zn and B caused significantly lower uptake of $\mathrm{Fe}$, in comparison to the treatment receiving all the nutrients. Reductions in uptake of $\mathrm{Fe}$ in all other nutrient's omission treatments were not found significant and they were at par with each other and the treatment receiving all the nutrients. The highest $\mathrm{Fe}$ uptake $28.73 \mathrm{mg}$ pot $^{-1}$ were observed in the treatment that received all the nutrients whereas the least uptake of $\mathrm{Fe}$ i.e. $13.82 \mathrm{mg}$ pot $^{-1}$ were associated with $\mathrm{N}$ omission treatment. Uptake of $\mathrm{Fe}$ in $\mathrm{K}, \mathrm{S}, \mathrm{Fe}, \mathrm{Mn}, \mathrm{Cu}$ and Mo omitted pots were found statistically at par with each other and that of the treatment receiving all the nutrients

\section{Manganese uptake}

It is obvious from the table 3 that the uptake of manganese by rice in the soil were significantly affected with application of different nutrient omission treatments. Omission of $\mathrm{N}, \mathrm{P}, \mathrm{Zn}$ and $\mathrm{B}$ caused significantly lower uptake of $\mathrm{Mn}$, in comparison to the treatment receiving all the nutrients. Reductions in uptake of $\mathrm{Mn}$ in all other nutrient's omission treatments were not found significant and they were at par with each other and the treatment receiving all the nutrients.

\section{Zinc uptake}

The data presented in table 3 revealed that the total $\mathrm{Zn}$ uptakes by rice in the soils were significantly affected with application of different nutrient omission treatments. Omission of $\mathrm{N}, \mathrm{P}, \mathrm{Zn}$ and $\mathrm{B}$ were recorded significantly lower uptake of $\mathrm{Zn}$ as compared to treatment that received all the nutrients. Treatment that received all the nutrients, recorded highest $\mathrm{Zn}$ uptake i.e. $5.75 \mathrm{mg} \mathrm{pot}^{-1}$ and the lowest $\mathrm{Zn}$ uptake were recorded as $2.62 \mathrm{mg} \mathrm{pot}^{-1}$ in $\mathrm{N}$ omission pots. Treatments of $\mathrm{K}, \mathrm{S}, \mathrm{Fe}, \mathrm{Mn}, \mathrm{Cu}$ and Mo omission were statistically at par with each other and the treatment that received all nutrients. Reductions in concentration of $\mathrm{Zn}$ with omission of $\mathrm{Zn}$ have been reported by Din et al., (2001) in chickpea. Supply of all the nutrients including $\mathrm{Zn}$ increased the availability of $\mathrm{Zn}$ in soil resulting in higher 
grain and straw yields causing higher $\mathrm{Zn}$ uptake (Mukhi and Shukla, 1991). Lower Zn uptake was observed with $\mathrm{N}$ and $\mathrm{P}$ omission since these two elements were most limiting.

Table.1 Effect of nutrient omission on uptake of nutrients by rice (MTU-1001)

\begin{tabular}{|c|c|c|c|c|c|c|c|c|c|c|c|}
\hline \multirow[t]{2}{*}{ Treatment } & \multicolumn{3}{|c|}{$\begin{array}{c}\text { Primary nutrients } \\
\text { uptake } \\
\left(\mathrm{g} \mathrm{pot}^{-1}\right)\end{array}$} & \multicolumn{3}{|c|}{$\begin{array}{c}\text { Secondary } \\
\text { nutrients uptake } \\
\left(\mathrm{g} \text { pot }^{-1}\right)\end{array}$} & \multicolumn{5}{|c|}{$\begin{array}{c}\text { Micronutrients uptake } \\
\left(\mathrm{mg} \mathrm{pot}^{-1}\right)\end{array}$} \\
\hline & $\mathbf{N}$ & $\mathbf{P}$ & $\mathbf{K}$ & $\mathbf{C a}$ & Mg & $\mathbf{S}$ & B & $\mathrm{Fe}$ & Mn & Zn & $\mathbf{C u}$ \\
\hline All & 1.6 & 0.3 & 1.9 & 1.0 & 0.6 & 0.2 & 1.6 & 28.7 & 41.1 & 5.8 & 1.2 \\
\hline All - $\mathbf{N}$ & 0.7 & 0.1 & 0.9 & 0.5 & 0.3 & 0.1 & 0.7 & 13.8 & 19.6 & 2.6 & 0.6 \\
\hline All - P & 1.0 & 0.2 & 1.3 & 0.7 & 0.4 & 0.2 & 1.0 & 18.7 & 27.3 & 3.7 & 0.8 \\
\hline All - $K$ & 1.5 & 0.3 & 1.8 & 0.9 & 0.5 & 0.3 & 1.4 & 27.1 & 37.8 & 3 & 1.2 \\
\hline All - S & 1.4 & 0.3 & 1.8 & 0.9 & 0.5 & 0.2 & 1.4 & 26.6 & 38.5 & 5.2 & 1.1 \\
\hline All - Fe & 1.6 & 0.3 & 1.9 & 1.0 & 0.6 & 0.3 & 1.5 & 28.1 & 41.1 & 5.6 & 1.2 \\
\hline All - Mn & 1.5 & 0.3 & 2.0 & 1.0 & 0.6 & 0.2 & 1.5 & 28.7 & 40.3 & 5.6 & 1.2 \\
\hline All - Cu & 1.5 & 0.3 & 1.8 & 0.9 & 0.6 & 0.2 & 1.4 & 26.9 & 38.7 & 5.3 & 1.1 \\
\hline All - Zn & 1.3 & 0.2 & 1.6 & 0.8 & 0.5 & 0.2 & 1.2 & 24.0 & 34.3 & 4.5 & 1.0 \\
\hline All - B & 1.3 & 0.2 & 1.7 & 0.8 & 0.5 & 0.2 & 1.2 & 25.3 & 35.5 & 5.0 & 1.1 \\
\hline All - Mo & 1.5 & 0.3 & 1.9 & 1.0 & 0.6 & 0.2 & 1.5 & 27.7 & 39.5 & 5.4 & 1.2 \\
\hline SEm \pm & 0.05 & 0.02 & 0.08 & 0.05 & 0.02 & 0.01 & 0.10 & 1.1 & 1.7 & 0.2 & 0.1 \\
\hline $\mathrm{CD}(\mathrm{P}=\mathbf{0 . 0 5})$ & 0.15 & 0.05 & 0.22 & 0.15 & 0.07 & 0.03 & 0.31 & 3.2 & 5.1 & 0.6 & 0.1 \\
\hline
\end{tabular}

Table.2 Effect of nutrient omission on growth and yield of rice (MTU-1001)

\begin{tabular}{|c|c|c|c|c|c|c|c|c|}
\hline Treatment & $\begin{array}{c}\text { Plant } \\
\text { height } \\
(\mathbf{c m})\end{array}$ & $\begin{array}{l}\text { Tillers } \\
\left(\text { no. }^{-1}\right. \\
\left.\text { pot }^{-1}\right)\end{array}$ & $\begin{array}{c}\text { Effective } \\
\text { tillers (no. } \\
\left.\text { pot }^{-1}\right)\end{array}$ & $\begin{array}{c}\text { Filled } \\
\text { grain }\left(\text { no. } \text { panicle }^{-1}\right)\end{array}$ & $\begin{array}{c}\text { Test } \\
\text { weight } \\
(\mathrm{g} 1000 \\
\left.\text { grain }^{-1}\right)\end{array}$ & $\begin{array}{l}\text { Grain } \\
\text { yield }(g \\
\left.\operatorname{pot}^{-1}\right)\end{array}$ & $\begin{array}{l}\text { Reduction } \\
\text { in grain } \\
\text { yield over } \\
\text { All }(\%)\end{array}$ & $\begin{array}{c}\text { Straw } \\
\text { yield }(g \\
\left.\text { pot }^{-1}\right)\end{array}$ \\
\hline All & 102 & 25 & 22 & 169 & 26.0 & 91 & - & 112 \\
\hline All - N & 91 & 16 & 13 & 121 & 25.7 & 41 & 55 & 56 \\
\hline All - P & 96 & 19 & 15 & 155 & 25.7 & 60 & 34 & 75 \\
\hline All - K & 101 & 24 & 22 & 164 & 25.9 & 85 & 6 & 106 \\
\hline All - S & 100 & 24 & 21 & 163 & 25.8 & 83 & 9 & 106 \\
\hline All - Fe & 100 & 24 & 21 & 166 & 25.9 & 89 & 2 & 113 \\
\hline All - Mn & 101 & 24 & 22 & 164 & 25.9 & 90 & 1 & 112 \\
\hline All - Cu & 101 & 24 & 21 & 165 & 25.8 & 86 & 6 & 106 \\
\hline All - Zn & 97 & 21 & 19 & 152 & 25.8 & 73 & 20 & 95 \\
\hline All - B & 97 & 21 & 19 & 157 & 25.8 & 78 & 13 & 99 \\
\hline All - Mo & 101 & 24 & 21 & 165 & 25.9 & 86 & 5 & 109 \\
\hline SEm \pm & 0.5 & 0.5 & 0.4 & 3.6 & 0.06 & 3.2 & - & 4.1 \\
\hline $\mathrm{CD}(\mathbf{P}=\mathbf{0 . 0 5})$ & 1.5 & 1.6 & 1.1 & 10.6 & NS & 9.6 & - & 12.1 \\
\hline
\end{tabular}


Table.3 Effect of nutrient omission on uptake of nutrients by rice (MTU-1001)

\begin{tabular}{|c|c|c|c|c|c|c|c|c|c|c|c|}
\hline \multirow[t]{2}{*}{ Treatment } & \multicolumn{3}{|c|}{$\begin{array}{c}\text { Primary nutrients } \\
\text { uptake } \\
\left(\text { g pot }^{-1}\right)\end{array}$} & \multicolumn{3}{|c|}{$\begin{array}{c}\text { Secondary } \\
\text { nutrients uptake } \\
\left(\text { g pot }^{-1}\right)\end{array}$} & \multicolumn{5}{|c|}{$\begin{array}{l}\text { Micronutrients uptake } \\
\left(\mathrm{mg} \mathrm{pot}^{-1}\right)\end{array}$} \\
\hline & $\mathbf{N}$ & $\mathbf{P}$ & $\mathbf{K}$ & $\mathbf{C a}$ & $\mathrm{Mg}$ & $\mathbf{S}$ & B & $\mathrm{Fe}$ & Mn & $\mathbf{Z n}$ & $\mathbf{C u}$ \\
\hline All & 1.6 & 0.3 & 1.9 & 1.0 & 0.6 & 0.2 & 1.6 & 28.7 & 41.1 & 5.8 & 1.2 \\
\hline All - N & 0.7 & 0.1 & 0.9 & 0.5 & 0.3 & 0.1 & 0.7 & 13.8 & 19.6 & 2.6 & 0.6 \\
\hline All - P & 1.0 & 0.2 & 1.3 & 0.7 & 0.4 & 0.2 & 1.0 & 18.7 & 27.3 & 3.7 & 0.8 \\
\hline All - $\mathbf{K}$ & 1.5 & 0.3 & 1.8 & 0.9 & 0.5 & 0.3 & 1.4 & 27.1 & 37.8 & 5.3 & 1.2 \\
\hline All - S & 1.4 & 0.3 & 1.8 & 0.9 & 0.5 & 0.2 & 1.4 & 26.6 & 38.5 & 5.2 & 1.1 \\
\hline All - Fe & 1.6 & 0.3 & 1.9 & 1.0 & 0.6 & 0.3 & 1.5 & 28.1 & 41.1 & 5.6 & 1.2 \\
\hline All - Mn & 1.5 & 0.3 & 2.0 & 1.0 & 0.6 & 0.2 & 1.5 & 28.7 & 40.3 & 5.6 & 1.2 \\
\hline All - Cu & 1.5 & 0.3 & 1.8 & 0.9 & 0.6 & 0.2 & 1.4 & 26.9 & 38.7 & 5.3 & 1.1 \\
\hline All - Zn & 1.3 & 0.2 & 1.6 & 0.8 & 0.5 & 0.2 & 1.2 & 24.0 & 34.3 & 4.5 & 1.0 \\
\hline All - B & 1.3 & 0.2 & 1.7 & 0.8 & 0.5 & 0.2 & 1.2 & 25.3 & 35.5 & 5.0 & 1.1 \\
\hline All - Mo & 1.5 & 0.3 & 1.9 & 1.0 & 0.6 & 0.2 & 1.5 & 27.7 & 39.5 & 5.4 & 1.2 \\
\hline SEm \pm & 0.05 & 0.02 & 0.08 & 0.05 & 0.02 & 0.01 & 0.10 & 1.1 & 1.7 & 0.2 & 0.1 \\
\hline $\mathrm{CD}(\mathrm{P}=0.05)$ & 0.15 & 0.05 & 0.22 & 0.15 & 0.07 & 0.03 & 0.31 & 3.2 & 5.1 & 0.6 & 0.1 \\
\hline
\end{tabular}

Table.4 Grain yields of wheat in relation to site specific nutrient dose and farmer's fertilizer dose

\begin{tabular}{|c|c|c|}
\hline S. No. & Treatment & Grain yield $\left(\mathbf{q} \mathbf{h a}^{-\mathbf{1}}\right)$ \\
\hline $\mathbf{1}$ & Site specific nutrient dose & 27.6 \\
\hline $\mathbf{2}$ & Farmers fertilizer dose & 23.7 \\
\hline
\end{tabular}

\section{Copper uptake}

The treatment receiving all nutrients were recorded the highest uptake of $\mathrm{Cu}$ i.e. $1.22 \mathrm{mg}$ $\operatorname{pot}^{-1}$ and the lowest uptake of $\mathrm{Cu}$ i.e. $0.56 \mathrm{mg}$ $\operatorname{pot}^{-1}$ was associated with $\mathrm{N}$ omission. Omission of $\mathrm{K}, \mathrm{S}, \mathrm{Fe}, \mathrm{Mn}, \mathrm{Cu}$ and $\mathrm{Mo}$ treatments were statistically at par with each other and treatment receiving all the nutrients. Increase in uptake of $\mathrm{Cu}$ with increasing levels of $\mathrm{Cu}$ spray has been observed by Gupta and Prasad (1989). Lower $\mathrm{Cu}$ uptake was observed with $\mathrm{N}$ and $\mathrm{P}$ omission because of lower grain and straw yields and lower $\mathrm{Cu}$ concentrations associated with these treatments.

\section{Verification at farmer's fields}

The N, P, Zn and B nutrients were identified as yield limiting nutrients based on the performance of rice crop during Kharif season 2017. These nutrients were applied at the rate of $150 \mathrm{~kg} \mathrm{~N}, 100 \mathrm{~kg} \mathrm{P}_{2} \mathrm{O}_{5}, 100 \mathrm{~kg} \mathrm{~K}_{2} \mathrm{O}, 7.5 \mathrm{~kg}$ $\mathrm{Zn}$ and $3 \mathrm{~kg} \mathrm{~B} \mathrm{ha}{ }^{-1}$. This dose, known as SSNM dose was tested at farmers field, from where the bulk soils were collected for pot experiments, with wheat crop (variety: GW273) during rabi season 2017-18. The wheat crop was shown on $15^{\text {th }}$ December 2017 and harvested on $4^{\text {th }}$ April 2018. The farmer's applied fertilizer doses at the rate of $80 \mathrm{~kg} \mathrm{~N}$ : $50 \mathrm{~kg} \mathrm{P}_{2} \mathrm{O}_{5}: 0 \mathrm{~kg} \mathrm{~K} \mathrm{O} \mathrm{ha}^{-1}$. 
The final grain yields of wheat in farmer's fields testing sites was recorded and presented in Table 4. The wheat grain yields at farmer's fields was higher in SSNM dose, applied based on the yield limiting nutrients, as compared to that of farmer's practice dose. About 14 to $17 \%$ increase in the wheat grain yield was recorded over farmer's practice dose. This testing confirmed that application of identified yield limiting nutrients as $\mathrm{N}, \mathrm{P}$, $\mathrm{Zn}$ and $\mathrm{B}$ in Alfisol, were the yield limiting nutrients. Many workers (Khurana et al., 2006, Khurana et al., 2008, Kumar, Balwant et al., 2018 and Kumar Bhupendra et al., 2018) reported similarly.

\section{References}

Ahmed, S., Elahi, N., Khan, R., Faridullah, J. and Din, N. 2010. Wheat response to phosphorus under climatic conditions of Juglote, Pakistan. Sarhad J. Agri., 26: 229-33.

Din, J., Rashid, A. and Zahid, M.A. 2001. Optimizing productivity and profitability in rain fed legume crops through balanced nutrient management. Pakistan J. Soil Sci., 20 (4): 70-74.

Chander, Girish, Verma, T. S. and Sharma, Sandeep. 2007. Influence of boron and farmyard manure on available boron and exchangeable calcium and their removal by cauliflower in the boron deficient soils of Himachal Pradesh. $J$. Indian Soc. Soil Sci., 55(1): 62-66.

Gupta, R.K. and Prasad, K. 1989. Effect of copper application on yield and nutrient uptake by Radish in acid soils of Nagaland. J. Indian Soc. Soil Sci., 37:74-76.

Havlin, J.L., Tisdale, S.L., Beaton, J.D. and Nelson, W.L. 2007. Soil fertility and fertilizers - an introduction to nutrient management. Dorling Kindersley Pvt. Ltd., New Delhi, India, 175.

Khurana, H. S., Phillips, S. B., Singh, B.,
Dobermann, A., Sidhu, A. S., Singh, Y. and Peng, S. 2006. Performance of sitespecific nutrient management for irrigated, transplanted rice in Northwest India. American Society of Agronomy, 10: 2134.

Khurana, H. S., Singh B., Dobermann, A, Phillips, S. B., Sidhu, A. S. and Singh, Y. 2008. Site specific nutrient management performance in a ricewheat cropping system. Better Crops India. pp. 26-28.

Kumar, Bhupendra, Sharma, G.K., Mishra, V.N., Chandrakar, T., Pradhan, A., Singh, D.P. and Thakur, A.K. 2018. Assessment of Yield Limiting Nutrients through Response of Rice (Oryza sativa L.) to Nutrient Omission in Inceptisols of Bastar District of Chhattisgarh State in India. Int. J. Curr. Microbiol.App. Sci., 7 (08): 3972-3980.

Kumar, Balwant., Sharma, G.K., Mishra, V.N., Pradhan, A. and Chandrakar, T. 2018. Assessment of Nutrient Deficiencies Based on Response of Rice (Oryza sativa L.) to Nutrient Omission in Inceptisols of Kondagaon District of Chhattisgarh in India. Int. J. Curr. Microbiol. App. Sci., 7(9): 350-359.

Mc-Beath, T., MMc-Laughlin, M.J., Armstrong, B.R.D., Bell, M., Bolland, M.D.A. Conyers, M.K., Holloway, R.E. and Mason, S.D. 2007. Predicting the response of wheat (Triticum aestivum L.) to liquid and granular phosphorus fertilisers in Australian soils. Australian J. Soil Res., 45: 448- 458.

Mishra, V. N., Patil, S. K., Das, R. O. Shrivastava, L. K., Samadhiya, V. K. and Sengar, S. S. 2007. Site-specific nutrient management for maximum yield of rice in Vertisol and InceptisolS of Chhattisgarh. A paper presented in South Asian Conference on "Water in Agriculture: management options for increasing crop productivity per drop of 
water", during November, 15-17, 2007 held at IGKV, Raipur (C.G.), India. pp. 136.

Mukhi, A.K. and Shukla, U.C. 1991. Effect of sulphur and zinc on yield and theiruptake in rice in submerged soil conditions. J. Indian Soc.Soil Sci., 39: 730-734.

Sahu, N., Mishra, V.N., Srivastava, L.K. and Jatav, G. 2017. Crop Response based Assessment of Limiting Nutrients using Site Specific Nutrient Management for Yield Maximization in Vertisols of Bemetara Districts of Chhattisgarh, India. Int. J. Curr. Microbiol. App. Sci., 6(6): 1784-1791.

Sharma, P.K., Yadav, G.L. and Kumar, S.
2000. Response of wheat to nitrogen and zinc fertilization. Indian J. Agro., 45(1): 124-127.

Singh, R. 2008. Effect of nitrogen management through organic and inorganic sources in sole and intercropped Bt cotton-wheat system. Ph.D. thesis, Division of Agronomy, Indian Agri. Res. Institute, New Delhi, India. p. 99

Syed, T.H., Ganai, M.R., Tahir Ali and Mir, A.H. 2006. Effect of nitrogen and sulphur fertilization on yield of and nutrient uptake by sunflower. J. Indian Soc. Soil Sci., 54(3): 375-376.

\section{How to cite this article:}

Bhupendra Kumar, G.K. Sharma, V.N. Mishra, T. Chandrakar and Thalesh Kumar. 2020. Crop Response Based Assessment of Soil Fertility through Nutrient Omission Technique in Alfisol of Bastar District of Chhattisgarh State in India. Int.J.Curr.Microbiol.App.Sci. 9(08): 40-50. doi: https://doi.org/10.20546/ijcmas.2020.908.005 